\title{
ISOLATION, SCREENING AND IN VITRO EVALUATION OF BACTERIAL ANTAGO- NISTS FROM SPENT MUSHROOM SUBSTRATE AGAINST COLLETOTRICHUM MUSAE
}

\author{
NP Ranathunge*, RJK Rajapaksha, K Yogarajah and MHWLI Preethikumara \\ Department of Agricultural Biology, Faculty of Agriculture, University of Ruhuna, Mapalana, Kamburupitiya, \\ Sri Lanka
}

Accepted: 2014 August 05

\begin{abstract}
Colletotrichum musae is a major pathogen in banana fruit which causes heavy losses at the postharvest stage. As a viable alternative to harmful chemical usage and physical control measures, the potential of using bacterial antagonist against $C$. musae was evaluated in this study. Out of a total of 92 bacterial isolates derived from dilution plates of aqueous extracts of spent mushroom substrate (SMS), 43 isolates were initially selected for screening for antagonistic activity against the $C$. musae isolate CMK01. Screening of the selected bacterial isolates revealed that 39 of the tested isolates significantly inhibited fungal growth in vitro compared to the control $(P<0.05)$. The diffusible substances secreted by the five selected isolates showed 100\% inhibition of colony growth, while (13-58\%) inhibition was observed with volatile compounds. Light microscopic observations revealed deformation and blackening of $C$. musae hyphal tips in the colony margins facing the antagonists. Four of the selected five bacterial isolates were identified with $100 \%$ precision as Pseudomonas aeruginosa based on partial $16 \mathrm{~S}$ rDNA sequences. These promising antagonists have the potential to be developed as effective biocontrol agents against $C$. musae.
\end{abstract}

Key words: Colletotrichum musae, bacterial antagonism, spent mushroom substrate, Pseudomonas aeruginosa

\section{INTRODUCTION}

The phytopathogenic fungus Colletotrichum musae is responsible for highly destructive anthracnose fruit rot in many Sri Lankan cultivars of banana that cause high postharvest losses (Perera et al. 1999). In Sri Lanka, of the total banana production, about $20-80 \%$ (Illeperuma and Jayathunge 2001) accounts for post harvest losses mainly due to diseases that could be prevented by proper handling and effective disease control. So far, various physical and chemicals treatments such as Calcium chloride and weak acids (Perera and Karunarathna 2001, 2002) plus highly toxic synthetic fungicides are been utilized to control the problem however, the anthracnose is still considered to be a major problem in harvested banana. With developing concerns on food safety and environmental issues, extensive research on selection of antagonists against post harvest fruit diseases is becoming increasingly popular. Biocontrol using antagonists involves the use of naturally occurring nonpathogenic microorganisms that are capable of reducing the activity of plant pathogens thereby suppressing the disease. The postharvest stage provides particular advantages to employ biological control as the controlled conditions in store houses can provide a unique environment ideal for biological systems.

The disease suppressive properties of composting materials are known for many decades and much scientific evidence have revealed favourable properties of composts for the management of plant diseases (Hoitink and Fahy 1986, Hoitink et al. 1997). Due to the unique chemical constitution present in spent mushroom substrate (SMS), it is inhabited by many microorganisms such as actenomycetes, bacteria and fungi, those which not only play a role in its further decomposition, but also exert antagonism to the normal pathogens surviving and multiplying in the ecosystem. Much scientific literature such as Yohalem et al. (1994), Yohalem et al. (1996) and Gea et al. (2011) discussed the potential utilization of aqueous extracts of SMS in controlling foliar diseases. Even though enumeration of SMS inhabiting microorganisms provide solid evidence for dis- 
ease suppressive and curative properties of SMS that emphasizes the effectiveness of direct utilization of mushroom compost or their aqueous extracts in agriculture, modern technology can be applied to improve this valuable source of antagonism much further in order to develop a commercially viable, highly efficient and environmentally sound biological control strategy.

The objective of the present study is to screen the presence of potential bacterial antagonists in spent oyster mushroom substrate against Colletotrichum musae and to evaluate their antifungal properties under in vitro conditions.

\section{METHODOLOGY}

\section{Isolation of the pathogen}

Colletotrichum musae (CMK01) was isolated from an infected fruit of the local cultivar "seeni kehel" (genotype ABB) collected in Matara district, Sri Lanka. The fruit tissue was swabbed with $70 \%$ ethanol and a small infected tissue was aseptically transferred to potato dextrose agar (PDA) medium and subsequently monoconidial cultures were prepared from sporulating cultures. The Pathogen was identified using morphology of the asexual conidia produced on PDA plates. The cultures were maintained at room temperature $\left(26- \pm 2^{\circ} \mathrm{C}\right)$ with $12 \mathrm{~h}$ light and dark cycles.

\section{Isolation of bacteria from spent mushroom substrate}

Four months old discarded oyster mushroom cultivation media (saw dust of mango wood with $10 \%$ rice bran, $0.2 \%$ Magnesium Sulphate and $2 \%$ Calcium Oxide) was used to isolate antagonists for this study. Hundred grams of the spent mushroom substrate (SMS) was suspended in $100 \mathrm{ml}$ of sterile distilled water and the aqueous suspension was filtered through four layers of sterilized cheesecloth. The filtrate was centrifuged at $3000 \mathrm{rpm}$ (DAMON) for 10 minutes. The supernatant was collected and subjected to serial dilution procedure using sterile distilled water. Two hundred microlitre aliquots of the suspensions of $10^{-4}$ and $10^{-6} \mathrm{di}$ lution levels were evenly spread on PDA media using a sterile bent glass rod. The plates were incubated at $28^{\circ} \mathrm{C}$ for $24 \mathrm{~h}$ to get single bacterial colonies. Well discriminating individual bacterial colonies were then transferred to fresh PDA media and were maintained until further used

\section{Screening for potential antagonists}

Initially, all the isolated bacterial isolates from SMS were screened for antagonistic activity against C. musae isolate CMK01 by dual culturing on PDA plates: A small agar plug $\left(5 \mathrm{~mm}^{2}\right)$ containing the pathogen was placed in the middle of the plate while four bacterial isolates were spotted near the periphery of the plate so that they were equidistant from the pathogen. The plates were sealed and incubated at room temperature for one week. The bacterial isolates that showed visible fungal inhibition were selected for the second round of screening on dual cultures (Sariah 1994) where, each selected bacterial isolate was smeared at one side of the PDA plate while an agar plug $\left(5 \mathrm{~mm}^{2}\right)$ of the test fungus was placed at the opposite end of the plate. The inverted plates were incubated at $28^{\circ} \mathrm{C}$. The treatments were arranged in completely randomized design with three replicates for each selected isolates and control of axenic CMK01culture. Three and five days after incubation, radius of each of fungal colony was recorded. Agar plugs obtained from the middle of the inhibition zones were cultured on fresh PDA plates in order to assess the viability of the fungus in the interaction zone at seven days after culturing. The percent inhibition of radial growth (PIRG) of the fungus was calculated for using the following formula:

$\mathrm{PIRG}=\mathrm{R}_{1}-\mathrm{R}_{2} / \mathrm{R}_{1} \times 100$

Where, $\mathrm{R}_{1}=$ Average radius of the $C$. musae colony in the control plate; $\mathrm{R}_{2}=$ Average radius of the C. musae colony subjected to antagonism. 
The results were subjected to the ANOVA procedure and the mean value of each interaction was compared against a control using the DUNNET'S test at $\mathrm{P}=0.05$ value using SAS 9.1.3 statistical software.

Five highly efficient antagonists were selected for further testing based on the above results.

\section{Production of diffusible and volatile anti- fungal substance}

For these assays five antagonists namely, B01, B04, B09, B34 and B39 were selected based on the results of the above screening experiment.

The effect of diffusible substances secreted by the antagonists was evaluated using the cellophane overlay technique (Nourozian et al. 2006). Cellophane membranes (gift wrap material) of $9 \mathrm{~mm}$ diameter were boiled in water for $5 \mathrm{~min}$ and autoclaved placing the cellophane membrane in between two paper towels. A sterile cellophane membrane was placed on the PDA medium in each petri plate and air dried under the laminar flow cabinet for 15 minutes. A $24 \mathrm{~h}$ old culture of bacterial isolate was suspended in a very small amount of SDW and the suspension was smeared over the entire surface of the cellophane. For the control experiment, SDW was applied on the cellophane membrane. The plates were incubated at $28^{\circ} \mathrm{C}$ for 48 hours after which the cellophane membrane smeared with bacterial culture was removed. A small disc of the $C$. musae isolate (CMK01) was placed in the centre of the plate. The plates were incubated at $28^{\circ} \mathrm{C}$ for 5 days and radius of the fungal colony was measured in each plate. The treatments were arranged in completely randomized design with 5 replicates. The results were expressed as percent inhibition of radial growth compared to the control.

The effect of volatile substances was evaluated according to the agar strip removal method as described by Choi et al. (2006). An agar strip ( $1 \mathrm{~cm}$ wide) was removed from the centre of a PDA plate and the plate was air dried under sterile conditions to remove excess moisture on the cut surfaces. Each bacterial isolate was streaked on the centre of one half of the PDA plate while an agar disc of the C. musae isolate (CMK01) was placed in the centre of the other part of the PDA plate. The culture plates were sealed and incubated at $28^{\circ}$ $\mathrm{C}$ for 5 days. The treatments were arranged in completely randomized design with 5 replicates. The results were expressed as means of percent inhibition of growth of C. musae in the presence and absence of bacterial isolate.

\section{Effect of antagonism on mycelial growth and morphology}

Seven Days after establishment on dual cultures, microscopic slides were prepared mounting the leading edges of the C. musae mycelia that growing towards the bacterial antogonist. A control mount was also prepared from the seven-day old contro, axenic $C$. musae (CMK01) culture. The mounts were observed under the binocular microscope ( $\mathrm{x}$ 40) to detect any alterations in mycelia growth and morphology.

\section{Molecular identification of antagonistic bacteria}

The five antagonists selected for above screening were identified using partial $16 \mathrm{~S}$ rDNA sequencing analysis at the microbial identification facility of CABI international organization in the United Kingdom.

\section{RESULTS}

\section{Screening for potential antagonists}

The C. musae isolate (CMK01) used for this study showed an average growth rate of $9 \mathrm{~mm}$ per day at $26- \pm 2^{\circ} \mathrm{C}$ and $12 \mathrm{~h}$ light/dark. The slightly pink mycelium was very compact and grew profusely on PDA medium. C. musae 
produced salmon pink colour spore masses as early as 7 days after culturing on PDA media at $26-28^{\circ} \mathrm{C}$ temperature. The fungus was confirmed as C. musae based on straight, cylindrical orange cinnamon colour conidia that were obtuse at the apex and truncate at the base (Bailey et al. 1992).

Figure 1. Co-culturing and initial in vitro screening of potentially antagonistic bacteria against Colletotrichum musae at 5 and 17 days after culturing (DAC). Centre of each plate (and the control plate) shows the fungus and the surrounding colonies with labels (isolate numbers) indicate 23 of the bacterial isolates used for the initial screening. Figures $\mathrm{A}, \mathrm{C}$ and $E$ : Clear inhibition zones were observed at 5 DAC except in isolates B02, B06, B07 and B33. Figures $B, D$ and F: At 10 DAC, colony margins of the inhibited fungus became dark and dense indicating growth termination.

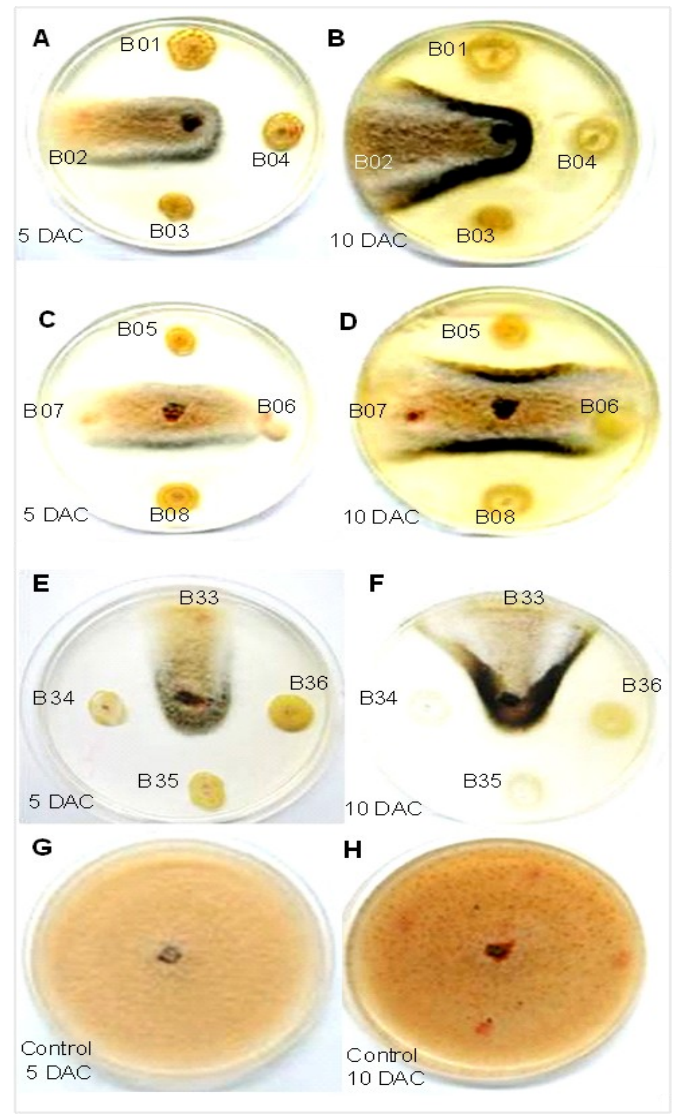

Initially, 92 morphologically different bacterial isolates were obtained from spent mushroom substrate and co cultured with $C$. musae to test antagonistic activity. From which, 43 isolates were selected for further screening based on formation of a clearly visible inhibi- tion zone between the bacterial and fungal colony by five days after culturing (DAC) (Figure 1).

The second round of screening of the selected 43 potential isolates on dual cultures with the C. musae isolate revealed that by 3DAC, 39 of the tested isolates significantly inhibited fungal growth in vitro compared to the control $(\mathrm{P}<0.05)$ (Table 1). Seven of these positive isolates namely B01, B04, B05, B09, B34, $\mathrm{B} 39$ and $\mathrm{B} 40$ showed more than $60 \%$ inhibition. The maximum inhibition value of $80 \%$ was exhibited by the isolate B09.

Five days after co culturing, the level of inhibition increased in 38 isolates of which, 21 showed more than $70 \%$ inhibition with a maximum value of $78.5 \%$ for the isolates B39 and B40 (Table 1).

Table 1. Mean Inhibition of radial growth of Colletotrichum musae isolate (CMK01) by antagonistic bacteria extracted from spent oyster mushroom substrate.

\begin{tabular}{|c|c|c|c|c|c|}
\hline \multicolumn{4}{|c|}{$\begin{array}{l}\text { Inhibition of radial } \\
\text { growth }(\%)\end{array}$} & \multicolumn{2}{|c|}{$\begin{array}{c}\text { Inhibition of } \\
\text { radial growth (\%) }\end{array}$} \\
\hline $\begin{array}{l}\text { Isolate } \\
\text { Number }\end{array}$ & $\begin{array}{c}\text { 3DAC* } \\
*\end{array}$ & $\begin{array}{l}\text { 5DAC } \\
* *\end{array}$ & $\begin{array}{l}\text { Isolate } \\
\text { Number }\end{array}$ & $\begin{array}{l}\text { 3DAC } \\
* *\end{array}$ & $\begin{array}{l}\text { 5DAC } \\
* *\end{array}$ \\
\hline B01 & 63.67 & 78.15 & B23 & 45.67 & 67.41 \\
\hline B02 & $02.67^{\#}$ & $00.74^{\#}$ & B24 & 50.00 & 69.63 \\
\hline B03 & 49.33 & 65.93 & B25 & 52.00 & 48.89 \\
\hline B04 & 61.67 & 77.04 & B26 & 50.67 & 65.04 \\
\hline B05 & 61.00 & 75.56 & B27 & 52.00 & 56.30 \\
\hline B06 & 19.67 & 39.63 & B28 & 51.67 & 66.37 \\
\hline B07 & 17.33 & 31.11 & B29 & 48.00 & 67.41 \\
\hline B08 & 50.00 & 69.63 & B30 & 55.67 & 72.59 \\
\hline B09 & 80.33 & 73.33 & B31 & 51.33 & 68.52 \\
\hline B10 & 58.00 & 74.81 & B32 & 55.67 & 71.48 \\
\hline B11 & 50.67 & 69.63 & B33 & $0.00^{\#}$ & $05.19^{\#}$ \\
\hline B12 & 57.00 & 73.33 & B34 & 64.00 & 78.52 \\
\hline B13 & 51.33 & 70.37 & B35 & 50.00 & 00.71 \\
\hline B14 & 56.67 & 73.70 & B36 & 56.33 & 70.00 \\
\hline B15 & 52.00 & 70.37 & B37 & 12.33 & 40.00 \\
\hline B16 & 45.33 & 67.41 & B38 & 58.67 & 73.33 \\
\hline B17 & 56.33 & 73.33 & B39 & 64.67 & 78.52 \\
\hline B18 & 49.67 & 71.85 & B40 & 63.00 & 77.04 \\
\hline B19 & 46.00 & 64.81 & B41 & 51.67 & 70.37 \\
\hline B20 & 53.67 & 72.96 & B42 & 32.00 & 51.11 \\
\hline B21 & $01.33^{\#}$ & $00.89^{\#}$ & B43 & $03.33^{\#}$ & $00.74^{\#}$ \\
\hline B22 & 39.33 & 63.70 & Control & 00.00 & 00.00 \\
\hline
\end{tabular}

Means with the symbol ${ }^{\#}$ are not significantly different from the control plate at $\mathrm{P}<0.05$ according to Dunnett's test. * Mean percentage inhibition of radial growth. ** Days after culturing. 
No mycelia growth was observed even seven days after incubation, when PDA plugs from the middle of the interaction zone was recultured on fresh PDA plates.

\section{Production of diffusible and volatile anti- fungal substance}

Experiment on diffusible substances revealed $100 \%$ inhibition of fungal growth on the third day after culturing (Table 2, Figure 2A). Fungal growth was not observed in those plates until 10 DAC.

Table 2. Mean growth inhibition of Colletotrichum musae isolate CMK01 by volatile and diffusible compounds produced by antagonistic bacteria.

\begin{tabular}{|l|c|c|}
\hline \multirow{2}{*}{$\begin{array}{c}\text { Isolate } \\
\text { number }\end{array}$} & \multicolumn{2}{|c|}{ Inhibition of radial growth (\%) at $3 \mathrm{DAC}^{\mathrm{b}}$} \\
\cline { 2 - 3 } & Volatile substances & Diffusible substances \\
\hline B01 & $13.33^{*}$ & 100.00 \\
\hline B04 & $19.26^{*}$ & 100.00 \\
\hline B09 & 05.19 & 100.00 \\
\hline B34 & $58.52^{*}$ & 100.00 \\
\hline B39 & $36.30^{*}$ & 100.00 \\
\hline Control & 00.00 & 000.00 \\
\hline
\end{tabular}

Means with the symbol * are significantly different from the control plate at $\mathrm{P}<0.05$ according to Dunnett's test.

${ }^{a}$ Mean percentage inhibition of radial growth. ${ }^{b}$ Days after culturing.
In the experiment on volatile antifungal substances, significant $(\mathrm{P}<0.05)$ growth inhibition was observed in isolates B01, B04, B34 and B39 compared to the control colony (mean diameter $2.7 \mathrm{~cm}$ ) by $3 \mathrm{DAC}$ (Table 2, Figure 2B).

\section{Effect of bacterial isolates on C. musae my- celial growth and morphology}

Light microscopic observations revealed that hyphal tips at the leading edge of the colony, that faced the bacterial smear was thick and deformed as opposed to smooth normal hyphae in the control colony (Figure 3). These deformation lead to total inhibition of fungal growth and blackening of the colony margins that faced the antagonists (Figures 1B, 1D and $1 F)$.

\section{Molecular identification of antagonistic bacteria}

According to the partial 16S rDNA sequence analysis, B01, B04, B34 and B39 isolates gave $100 \%$ matches to the species Pseudomonas aeruginosa when subjected to BLAST search. B09 was not able to identify since the sequencing reaction failed.

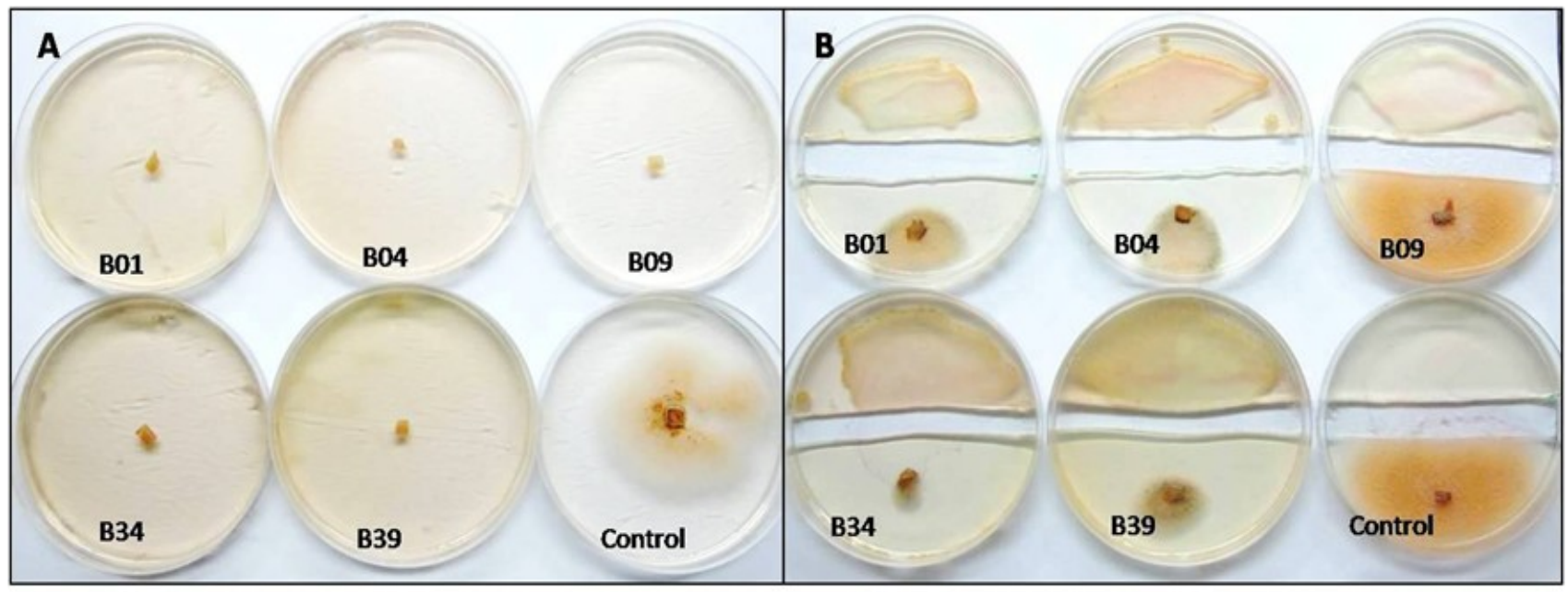

Figure 2: In-vitro screening for diffusible (A) and volatile (B) antifungal compounds produced by antagonistic bacteria against Colletotrichum musae isolate CMK01 three days after culturing. 


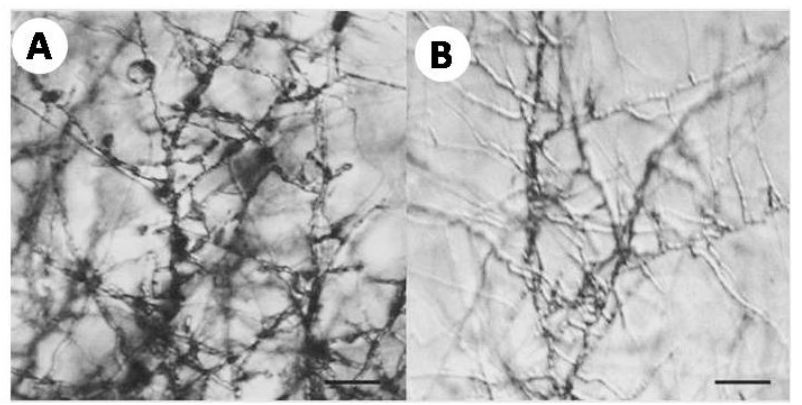

Figure 3: Light micrographs showing the effect of bacterial antagonism on hyphal growth (A) of Colletotrichum musae isolate CMK01 compared to a control mycelium (B). Bars $=20 \mu \mathrm{m}$

\section{DISCUSSION}

Results of this study clearly showed the potential of using antagonistic bacteria from spent mushroom substrate to control C. musae infecting banana.

There are various bacterial species, fungal and actinomycete groups that occur in the spent mushroom substrate are known to have antagonistic features. Ranathunge et al. (2012) reported isolation of sixteen different bacterial antagonists from aqueous extracts of SMS against $C$. gloeosporioides in papaya. Many different antagonistic bacterial species have been reported to inhabit SMS that include $B a$ cillus licheniformis, B. subtilis, Paenibacillus macerans, Pseudomonas aeruginosa and Streptomyces albidoflavus (Romaine and Holcomb 2000, Viji et al. 2003, Phae et al. 1990).

In this study, four of the most promising bacterial isolates were identified as Pseudomonas aeruginosa using partial 16S rDNA sequencing analysis which gave numerous matches up to $100 \%$ to this species. Pseudomonas aeruginosa is a very common bacterium in the environment. There are numerous citations in published literature regarding the inhibitory properties displayed by this species towards Colletotrichum. For example, Rahman et al. (2007) reported occurrence of antagonistic Pseudomonas aeruginosa strains from the fructospehere of papaya against C. gloeosporioides. Masyahit et al. (2009) also reported the antagonistic association between Pseudomonas aeruginosa and C. gloeosporioides in dragon fruit. There are many other reports on the efficacy of Pseudomonas aeruginosa as a potential biocontrol agent for various phytopathogenic fungi (Siddiqui and Shaukat 2002, Mansoor et al. 2007, Prakob et al. 2009, Deshwal 2012, Maiti et al. 2012).

The results of the present study demonstrated that the antagonistic isolates produce antifungal compounds in vitro that inhibited mycelia growth of C. musae. Death and blackening of hyphae at the colony margins could be due to the toxic effect of antifungal substances which interfere with normal growth and multiplication. Pseudomonas strains are known to produce numerous compounds which are responsible for disease control. These inhibitory compounds are siderophores, HCN, degradative extracellular enzymes such as chitinase, protease, cellulose, $\beta-1,3$ glucanase and antibiotics such as pyrrolnitrin, pyoluteorin, phenazine (Dowling and O'gara, 1994, Choi et al.., 2006, Deshwal et al., 2011, Maiti, et al.. 2012). Similar observations have been reported with respect to Bacillus spp. antagonistic to Colletotrichum spp. (Sariah, 1994; Rahman et al, 2007).

The present study revealed that $P$. aeruginosa is capable of producing volatile substances and diffusible substances with antifungal properties that significantly inhibited the mycelia growth of $C$. musae on PDA. Production of volatile antimicrobials by $P$. aeruginosa has also been reported in numerous occasions (Baligh et al. 1996, Conway et al. 1989, Rahman et al. 2007, Maiti, et al. 2012). This approach offers an efficient, economical and environmentally sound means of suppressing the disease. However, further studies are required to evaluate the in vivo efficacy of the antagonists as well as to determine the time of application and the most suitable form in which the antagonists can be applied on fruits. 


\section{CONCLUSION}

In this study, $P$. aeruginosa isolates showed potential agonistic activity against $C$. musae causing anthracnose fruit rot of banana.

\section{REFERENCES}

Bailey JA, O'Connell RJ, Pring RJ, Nash C 1992 Infection strategies of Colletotrichum species. In: Colletotrichum: Biology, pathology and control, CAB International, Oxon, U.K. pp. 88-120.

Baligh M, Conway KE and Delgado MA 1996 Production of Ammonia b y Pseudomonas cepacia and Pseudomonas aeruginosa: Quantification and Effect on Host and Pathogen. In: Recent Research Developments in Plant Pathology, Pandalai, S.G. (Ed.). Vol. 1. Research Signpost, Trivandrum, India, pp: 19.

Choi GJ, Kim JC, Park EJ, Choi YH, Jang $\mathrm{KS}$, Lim HK, Cho KY and Lee S W 2006 Biological control activity of two isolates of Pseudomonas fluorescens against rice sheath blight. Plant Pathology Journal, 22(3): 289-294.

Conway KE, Foor CJ, Malvick D and Bender C 1989 Inhibition by Pseudomonas cepacia, a potential biocontrol agent, of selected soilborne pathogens. Phytopathology, 79: 1159-1159.

Deshwal VK 2012 Pseudomonas aeruginosa as biological control agent against plant pathogenic fungus Sclerotina sclerotiorum. International Journal of Plant, Animal and Environmental Sciences, 2(1): 14-17

Deshwal VK, Devi MS, Bhajanka N, Mistri J, Bose A and Saini N 2011 Pseudomonas aeruginosa strains and their role in plant growth promotion in medicinal plant. Global Journal of Applied Agricultural. Research, 1: 49-55.

Dowling DN and O'Gara F 1994 Metabolities of Pseudomonas involved in the biocontrol of plant disease. Trends in Bio- technology, 12:133-141.

Gea FJ, Santos M, Diánez F, Tello JC and Navarro MJ 2011 Effectiveness of Compost Tea from Spent Mushroom Substrate on Dry Bubble (Lecanicillium Fungicola). Proceedings of the $7^{\text {th }}$ International Conference on Mushroom Biology and Mushroom Products (ICMBMP7) 190-195.

Hoitink HAJ and Fahy PC 1986 Basis for the control of soilborne plant pathogens with composts. Annual Review of Phytopathology 24:93-114.

Hoitink HAJ, Rose MA and Zondag RA 1997 Composted Biosolids: An Ideal Organic Amendment for Container Media Supplying Both Nutrients and Natural Suppression of Root Rots. In: Ornamental Plants, Special Circular 154, Ohio State University Extension. January. Pp. 5861.

Illeperuma CK, Jayathunge KGLR 2001 Osmo -air dehydration of overripe "kolikuttu" banana. Journal of National Science Foundation Sri Lanka 29 (1\&2): 51-59.

Maiti CK, Sen S, Paul AK and Acharya K 2012 Pseudomonas aeruginosa WS-1 for biological control of leaf blight disease of Withania somnifera. Archives of Phytopathology and Plant Protection, 45 (7): 796-805

Mansoor F, Sultana V and Ehteshamul-Haque S 2007 Enhancement of biocontrol potential of pseudomonas aeruginosa and paecilomyces lilacinus against root rot of mungbean by a medicinal plant Launaea nudicaulis L. Pakistan Journal of Botany, 39(6): 2113-2119

Masyahit M, Sijam K, Awang Y and Satar MGM 2009 In vitro assay of factors affecting the growth of pathogens associated with diseases on dragon fruit (Hylocereus spp.) in peninsular Malaysia. Plant Pathology Journal, 8(4): 144151.

Nourozian J, Etebarian HR and Khodakaramian G 2006 Biological control of Fusarium graminearum on wheat by 
antagonistic bacteria. Songklanakarin Journal of Science and Technology, 28: 29-38.

Perera AN and Karunaratne AM 2002 Postharvest calcium chloride treatments do not help to increase shelf-life of bananas. Fruits, 57: 87-94.

Perera ODAN and Karunaratne AM K 2001 Response of bananas to postharvest acid treatments. Journal of Horticultural Science and Biotechnology, 76 (1): 70-76.

Perera ODAN, Basnayake BMKMK and Karunarathna AM 1999 Physicochemical characteristics, popularity and susceptibility to anthracnose of some local banana cultivars. Journal of the National Science Foundation of Sri Lanka, 27: (2) 119-130.

Phae CG, Saski M, Shoda M and Kubota H 1990 Characteristics of Bacillus subtilis isolated from composts suppressing phytopathogenic microorganisms. Soil Science and Plant Nutrition, 36:575586.

Prakob W, Nguen-Hom J, Jaimasit P, Silapapongpri $\mathrm{S}$, Thanunchai $\mathrm{J}$ and Chaisuk $\mathrm{P}$ 2009 Biological control of lettuce rootknot disease by the used of Pseudomonas aeruginosa, Bacillus subtilis and Paecilomyces lilacinus. Journal of Agricultural Technology, 5(1): 179-191.

Rahman MA, Kadir J, Mahmud TMM, Rahman RA and Begum MM 2007 Screening of Antagonistic Bacteria for Biocontrol Activities on Colletotrichum gloeosporioides in Papaya. Asian Journal of Plant Sciences, 6(1): 12-20.

Ranathunge NP, Gunathilaka S, Rajapaksha JC and Rajapaksha RJK 2012 Screening of potential bacterial antagonism in aqueous extracts of spent oyster mushroom substrate against Colletotrichum gloeosporioides causing anthracnose disease in papaya. Proceedings of the $9^{\text {th }}$ Academic sessions of the University of Ruhuna, $22^{\text {nd }}$ February 2012. P. 71

Romaine CP and Holcomb EJ 2000 Spent mushroom substrate: a novel multifunctional constituent of potting medium for plants. Mushroom News, 49: 4-15.

Sariah M 1994 Potential of Bacillus spp. as a biocontrol agent for anthracnose fruit rot of chilli. Malays. Applied Biology, 23: 53-60.

Siddiqui IA and Shahid Shaukat S 2002 Mixtures of plant disease suppressive bacteria enhance biological control of multiple tomato pathogens, Biology and Fertility of Soils, 36: 260-268.

Viji G, Uddin W and Romaine 2003 Suppression of gray leaf spot of perennial ryegrass turf by Pseudomonas aeruginosa from spent mushroom substrate. Biological Control, 26: 233-243.

Yohalem DS, Harris RF and Andrews JH 1994 Aqueous extracts of spent mushroom substrate for foliar disease control. Compost Science, 2:67-74.

Yohalem DS, Nordheim EV, and Andrews JH 1996 The effect of water extracts of spent mushroom compost on apple scab in the field. Phytopathology, 86:914922. 